\title{
DAŽI 19. GS. ZEMGALES IEDZĪVOTĀJU MŪŽA ILGUMA UN NĀVES CĒLON̦I PĒC ANTROPOLOGISKO EKSPEDĪCIJU MATERIĀLIEM
}

1939. gadā LU Anatomijas institūts, sadarbojoties ar Tautas dzīvā spēka institūtu, Zemgales novada trīs pagastos laikā no jūnija līdz vasaras beigăm īstenoja antropologiiskās izpētes programmu, kurā nozīmīga vieta bija atvēlēta arī sociālās antropologiijas problēmām. Cilvēku aptaujas sada|ā, kuru izveidoja J.Prīmaņa vadītā Anatomijas institūta līdzstrādnieki un Tautas dzīvā spēka institūta darbinieki, ietilpa vairāki demogrāfiskā, genealog̉iskā, mediciniskā un sociālā virzienā motivēti jautājumi.

Kādas bija ieceres, apkopojot un izvērtējot šo milzīgo materiālu, mēs nezinām, jo Otrais pasaules karš părtrauca iesāktos antropologiskos pētịjumus Latvijā, turklāt lielākã dala pētnieku aizklīda svešumā, tã arī nepaspējot apstrādāt un apkopot darba rezultātus. Tāpēc arī Zemgales novada antropologisko ekspedīciju materiāli (veidlapas) vairāk nekā 50 gadu nogulēja Jēkaba Prīmaņa Anatomijas muzeja krājumā. Lai šos materiālus varētu izmantot ne tikai antropologiskiem secinājumiem, bet arī kā vēstures avotu, ko varētu sabalsot ar dokumentētās vēstures avotiem, bija nepieciešams pārbaudīt un apkopot tâs plašo sociālās aptaujas da|u. Antropolog̉iskā ekspedīcija prof. J. Prīmaña vadībā veica pētījumu Zemgales novada Sīpeles, Līvbērzes un Bērzmuižas pagastā, fiksējot antropologiiskajās anketās cilvēku atmiņas par savu priekšteču (dzimtas loceklu tēva un mātes līnijā) identitāti, mūža ilgumu un nāves cêloni. Antropologiskā ekspedīcija, kuras pētnieki (K. Arāja vadībā) 1939. gada vasarā aptaujāja un izpētỉja Sīpeles pagastā 630 cilvēku ${ }^{1}$, Līvbērzes pagastā - 731 cilvēku² ${ }^{2}$, bet Bērzmuižas pagastā - izpētīja 1176 cilvēkus $^{3}$. Kopumā aptaujāti un antropologiski izpētīti 2279 cilvēki, sākot no jaundzimušiem bērniem līdz pat 97 gadus veciem sirmgalvjiem.

Pamatojoties uz atzîto vienas paaudzes aptuveno rādītāju (30-33 gadi), vecuma struktūra |ãva sadalīt visu Zemgales novadā izpētīto antropologisko materiālu trijās vecuma grupās jeb paaudzẽs. Pirmā jeb vecākā paaudze (dzim. no 1842. lĩdz $1880 \mathrm{~g}$ ) aptvēra $22 \%$ no visu izpētīto iedzīvotāju skaita, kas kopumã ataino tã laika demogrāfisko struktūru. Absolūtos skaiţ̦os šo paaudzi pārstāv 504 antropologiiskai izpētei paḳlauti cilvēki. 
Ielūkosimies šo cilvēku, kas dzima 19. gs. vidū un otrajā trešda|ā (no 1842. līdz 1880. gadam) un kuru vecums 1939. gadā bija no 64 līdz 95 gadiem, dažos dzimtu vēstures rādītājos, kā tos fiksējusi vinu atmiṇa. Turklāt tieši vecākā paaudze pārstāv to laiku vēsturē, kad tiek uzskatīts, ka dzimtas saknes, tātad atmiṇa par savas dzimtas piederīgajiem, varēja būt visstiprākā. Mums ir iespēja ielūkoties cilvēku atmiñas īpatnībās, izsekojot savus senčus ne tikai tēva, bet arī mātes līnijā. Uzskatāmības labad viss materiāls sadalīts atsevišķās piecgadēs (1. tab.).

Kopumā Zemgales novada vecākie cilvēki, kas aptaujas laikā bija 84-97 gadu veci (dzimuši no 1842. līdz 1855. gadam), veidoja 27 cilvēku lielu kopu. Sīpeles pagasta vecākā iedzīvotāja, ko 1939. gadā anketēja, bija Jūle Brigadere, dzim. Dreimane (dz. 1844.g.). Viñas saknes tēva līnijā gan meklējamas Dobeles apkārtnē, toties mātes senči (Meilandu dzimta) izsenis bijuši sīpelieši. Tāpēc par īsti vecāko Sīpeles pagasta iedzīvotāju gan mātes, gan tēva līnijā jâuuzskata Kārlis Silindriķis, kas dzimis 1845. gadā. Gan viṇa tēva Anša Silindriḳa, gan arī mātes - Lavīzes, dzim. Sildedzis, saknes meklējamas Bērzmuižas pagastā. Šĩs abas saradojušãs dzimtas, kā to liecina J.Strauberga pētîjumi, ${ }^{4}$ minētas dokumentos no 1780. gada. Arī 1853. gadã dzimusĩ Emīlija Komandiers, dzim. Dziedre, pārstāv vienu no senākajām Sīpeles pagasta dzimtām, kuras saknes iestiepjas vēl 17.gs. un 18.gs. ${ }^{5}$

Līvbērzes pagasta vecākās iedzīvotājas 1939. gadā bija 94 gadus vecā Karlīne Ercbergs, dzim. Šteinerts (dz. 1845.g.), un 92 gadus vecā Līna Freimentāls, dzim. Zommers (dz. 1847.g.). Zommeri (ğim. nr. 253) Šajā pagastã minēti 1851. gada revĩzijā, ${ }^{6}$ Ercbergi - 1858. gada revīzijā (g̀im. nr. 38). ${ }^{7}$

Savukārt Bērzmuižas pagasta vecākais dzīvojošais iedzīvotājs bija 97 gadu vecais Kristaps Brūms (dzimis 1842. gadā Bērzmuižas pagastā). Viņš bija savam laikam un kārtai tik kolorīta personība, ka acīmredzot piespiedis ārstu Kārli Arāju fỉksēt antropologiskajā anketā viṇa savdabīgo credo: kad bijis jauns, tēvs devis maizi, tagad dēls dod, strādājis nekad neesot. ${ }^{8}$ Arī visi tẽva un mātes senči (Freibergi) vairākās paaudzēs dzimuši šajā pagastā. Viṇš arī vienīgais no savas paaudzes atcerējās un zināja sava tēvatēva un tẽvamātes vārdu, atcerējās pat to, ka tēvatêvam un têvamātei uzvārdu vēl nebija. Šis cienijjamais 97 gadus vecais sirmgalvis gan bija aizmirsis, mātes tēva vārdu, toties atcerējās vienīgi mātesmātes vārdu Lība. Viṇš arī vienīgais no savas paaudzes 9 aptaujātajiem cilvēkiem zināja savu senču miršanas vecumu; neviens no viṇiem nebija nodzĩvojis ilgāk par 80 gadiem.

\section{Mũža ilgums}

Viens no demogrāfiskās programmas rādītājiem, kas bija ietverts tālaika antropologiiskajā anketā, fiksēja vecāku un vecvecāku (gan têva, gan mātes līnijā) dzīves ilgumu un nāves cêloni. Pārlūkojot anketās ierakstîtos mūža ilguma un nāves cēloṇu datus, var secinăt, ka vispārpieṇemtie priekšstati par iepriekšểjo paaudžu spēcīgo fizisko uzbūvi un ilgo mūžu, it īpaši sieviešu vidū, ir stipri pārspīlēti un shematizēti. Zinătnieku interesi izraisa ne tikai iespēja pārliecināties, ko 
un cik par savas dzimtas iepriekšẹjām paaudzēm, to slimīiaam un nāves cēloṇiem atcerējās paši cilvēki, bet arī paaudžu atmiṇā saglabājušãs miršanas diagnozes.

Vecākajā grupā iedzīvotāju (dzimuši 1842.-1855. gadā) têvu mūža ilgumu un nāves cêloni spēja atcerēties $74 \%$ aptaujăto (2. tab.). Spriežot pēc vinuu atmiṇām, tēvu, t.i., iepriekšejāās paaudzes vīriešu, dzīves ilgums bijis loti dažāds, sākot no 30 gadiem līdz pat 95 gadiem. Lielākoties tas svārstijāa no 50-60 līdz 90-95 gadiem. Vidējais tēva mūža ilgums līdz ar to bija aptuveni 72,2 gadi.

No tās vecuma grupas cilvēkiem, kas 1939. gadā bija 79-83 gadu veci (dzimuši 1856. -1860g.), sava tēva mūža ilgumu un nāves cēloni atcerējās $78,9 \%$ aptaujāto. Pēc šo cilvēku atminām tēvu mūža ilgums svārstījies no 35 lĩdz 90 gadiem, tomêr visbiežāk bijis 59-90 gadu. Tādējādi iepriekšějās paaudzes vĩriešu vidējais mūža ilgums, pēc vinuu bērnu sniegtajām ziṇām, bija 76,7 gadi.

To cilvēku vecuma grupā, kam 1939.g. vasarā bija 74-78 gadi (dzimuši 1861.-1865.g.), têva mūža ilgumu un nāves cēloni atcerējās $94,2 \%$ cilvēku. Pēc viṇu sniegtajām ziñām, iepriekšęjās paaudzes vīriěsu (têva) miršanas vecums svărstījās no 35 līdz 107 gadiem, vidēji tas bijis 70,8 gadi.

Savukārt starp cilvēkiem, kas dzimuši 1866.-1870. gadā, ziṇas par tēva mūža ilgumu sniedza $93 \%$ aptaujāto. Pēc viṇu sacîtā, tẽvu dzìves ilgums bijis no 30 līdz 94 gadiem, vidēji - 68,2 gadi.

No 64 līdz 68 gadus veciem aptaujātajiem (1871.-1875.g. dzimušajiem) ziņas par têva mūža ilgumu un nāves cēloni sniedza $92,9 \%$. Viṇu tễu mūža ilgums svārstījies no 25 lîdz pat 100 gadu vecumam; vidēji tas bijis 68,4 gadi. Šajā ziṇā saãs vecuma grupas cilvēku atmiṇas līdzinās iepriekšẹjās vecuma grupas cilvēku sacītajam. Varam secināt, ka tâs, visai iespējams, ataino reālo dzīves ainu.

Jaunākie no Zemgales novada vecākajā paaudzē aptaujātie, kam 1939. gadā bija 59-63 gadi (dzimuši 1876.-1880.g.), tēva mūža ilgumu un nãves cêloṇus atcerējās $93,7 \%$ gadījumu. Trim cilvēkiem no sãs grupas $(2,2 \%)$ tēvi vêl bija dzīvi. Augustes Bučinas tēvam Jānim Klavierim no Džūkstes pagasta tolaik bija 87 gadi (dz. 1852.g.), Līvbērzes pagasta iedzīvotājas Emīlijas Brancis tēvam Kārlim Švānam bija 100 gadu (dz. 1839.g.), bet 60 gadu vecais Bērzmuižas iedzīvotājs Krišjānis Brūms (dz, 1879.g.) atsaucās uz savu vēl dzīvo un rakstā jau pieminēto 97 gadus veco tēvu Kristapu Brūmu (dzimtas Nr. 266).

Pēc vinuu sacîtā, iepriekšejāās paaudzes vīriešu mūža ilgums svārstījies no 30 lĩdz pat 102 gadiem. Vidējais mūža ilgums bija 71,6 gadi. No šis grupas aptaujātajiem cilvēkiem, kam pašiem bija 59-63 gadi, divi cilvēki atzina, ka viṇu tēvi vēl ir dzīvi. Tã, Emīlija Brancis, dzim. Šẽnbergs, no Sīpeles pagasta stāstīja, ka vinas tēvam Kārlim Šēnbergam esot 100 gadu (dz. 1839. gadā).

Kopumā no vecākajā paaudzẽ aptaujātajiem ziņas par têva mūža ilgumu un nāves cêloni varēja sniegt $91.3 \%$ cilvēku. No 59 līdz 74 gadu vecumam atmiṇas par tēva mūža ilgumu bịja saglabājuši 93-94\% cilvēku. Vecāka gada gājuma cilvēkiem, 
īpaši pēc 83 gadu vecuma, atmiṇa bija vājāka. To cilvēku grupā, kuri bija 59-68 gadu veci, 1,1\% gadījumu têvs vêl bija dzīvs; tēviem šajā laikā bija 87-100 gadu.

Sava tēva mūža ilgumu Zemgales novada vecākā paaudze vērtēja no 25 līdz 107 gadiem, vidēji - 69,2 gadi. Tas nozīmē, ka iepriekšējās paaudzes vīriešu vidējais mūža ilgums bijis daudz îsāks par maksimāli nosaukto un arī daudz ìsāks par mūsu priekšstatos iztēloto priekšteču visai ilgo mūžu, turklāt neaizmirsīsim, ka ziṇas sniedza ilgdzīvotāju paaudze.

Tas, kā savu mūža garumu vērtē vecākā paaudze, iespējams visai reāli atspoguḷo îstenību. Šajā ziṇā uzmanība jāvērš̌ uz kādu tendenci, ko fiksē iepriekšẹjā paaudzē konstatētā atškirirỉba starp to, kā mūža ilguma samazinājumu atceras cilvēki, kas paši dzimuši laikā no 1861. lĩdz 1865. gadam un no 1866. līdz 1870. gadam. Šĩ tendence iespējams nav subjektīva, saistîta ar atmiṇas îpatnībām, bet tā varētu arī norādīt uz kādu objektīvu šās parādības cēloni. Toties to cilvēku atmiṇa, kuri bija vecāki par 75 gadiem, škiet, vairs neatspogulo realitāti.

Ziṇas par mātes mūža ilgumu un nāves cēloni visvecākajā Zemgales novada iedzīvotāju grupā (dzimuši 1842.-1855.g.) varēja sniegt $48,2 \%$ aptaujāto, kas ir gandrīz uz pusi mazāk nekā to, kas atceras têva mūža garumu (3. tab.). Pềc viṇu sacītā, mātes dažādu cêloṇu dē| vai nu mira loti jaunas, sâkot no 26 gadu vecuma, vai arī nodzīvoja līdz pat 98 gadiem. Vairākumā gadījumu gan mūža ilgums svārstijjās no 60 līdz 98 gadiem, tomēr visbiežāk - no 50 līdz 90 gadiem. Vidējais mūža ilgums bija 68,6 gadi, un, kā izriet no viṇu jau sirmo bērnu atmin̄ām, tas bija pat mazāks par vĩriešu vidējo mūža ilgums 18 .gs. beigās.

To cilvēku grupā, kuri dzimuši no 1856. līdz 1860. gadam, mātes miršanas vecumu un nāves cêloni atcerējās $84,2 \%$ aptaujāto. Pēc šo cilvēku atmināām, iepriekšejjầs paaudzes sieviešu mūža ilgums svārstījies no 56 lĩdz pat 102 gadiem (vidēji 73,2 gadi).

To cilvēku vecuma grupā, kuri dzimuši no 1861. līdz 1865.g., mâtes mūža ilgumu un nāves cêloni zināja 84,1 \% aptaujāto. Viṇu mātes dzīves ilgums svārstịjies no 33 līdz 102 gadiem (vidēji 65,6 gadi).

No cilvēkiem, kas 1939. gadā bija 69-73 gadu veci (dzimuši 1866.-1870.g.), mātes mūža ilgumu zināja $87 \%$ aptaujāto, un vini to vêrtēja no 37 līdz 100 gadiem. $2 \%$ aptaujātajiem mātes vēl bija dzīvas. Piemēram, Kristapa Ercberga mătei Karlīnei Šteinertei no Līvbērzes pagasta bija 94 gadi, bet Sesavas pagasta iedzīvotāja Jāna Grenberga mātei Trīnei Nākums 1939. gadā bija 89 gadi. Pẽc bêrnu atmiñām, vidējais mātes mūža ilgums bija 69,6 gadi.

To cilvēku vecuma grupā, kas dzimuši 1871.-1875.g., mātes mūža ilgumu un nāves cêloni zināja $92,1 \%$ aptaujāto. Pēc viṇu atmiņām, mātes mūža ilgums svārstījies no 28 lĩdz 100 gadiem (vidēji 70,4 gadi). Izbrīnu rada tas, cik loti šie dotumi atbilst tēvu datiem. Tie apliecina divas tendences: pirmkărt, arvien lielāks skaits cilvēku mirst jauni (no slimībām), otrkārt, tie uzrāda iespējami ilgāku mūžu. Arī starp šãs grupas cilvēkiem bija tādi, kuru mātes vēl bija dzīvas $(3,1 \%)$. Sīpeles 
Gulbju māju iemītnieka Kār|a Švāna mātei Lĩbai Legzdai bija 87 gadi (dz. 1859), Vecmuižas iedzīvotājas Annas Mūrnieks mātei Trīnei Mundrejs bija 88 gadi (dz. 1851.g.). Līvbērzes pagasta iedzìvotājas Vilhelmīnes Ulmanes, dzim. Valtmanis, māte Marija Bankoviča bija 85 gadus veca (dz. 1854.g.).

To cilvēku vecuma grupā, kuri dzimuši 1876.-1880.g., mātes mūža ilgumu un nāves cēloni zināja $87,4 \%$; 7\% no šiem aptaujātajiem mātes vēl bija dzīvas. Pēc vinu sniegtajām zin̄ām, mātes mūža ilgums bijis no 26 līdz 102 gadiem (vidēji 70,4 gadi).

Izvērtējot iepriekšējās paaudzes sieviešu mūža ilgumu, jāatzīmē divas tendences: pirmā no tām rāda, ka mūža ilgums samazinājies 1861.-1865. gadā dzimušo cilvēku mātēm (tâpat kā vīriešu līnijā); otrā - nepārprotami atspēko vispāratzīto viedokli par to, ka sievietes dzīvojušas ilgāk. Te gan jāatrunā, ka vērtējot mūža ilgumu, nav nnemti vêrā bērnu mirstības rādītāji.

Apkopojot visvecākās iedzīvotāju grupas atmiņas, jāsecina, ka tēva un mātes vidējais mūža ilgums, ieskaitot arī agri mirušos, nepārsniedza 70 gadu robežu. Tomēr bija cilvēki, īpaši vĩrieši, kas sasniedza ilgdzīvotības rekordu - 75-95 gadus. Vienlaikus bija cilvēki, gan vīrieši, gan sievietes, kas mira jauni (26-30 gadu vecumā); \ajā gadījumā nāves cēlonis varēja būt kāda slimība.

Ziṇas par tễvatêvu, viṇa mūža ilgumu un nâves cêloni, starp gados visvecākajiem aptaujātajiem Zemgales novada iedzīvotājiem ( 1842.-1855.g. dzimušajiem) spēja sniegt trīs $(11,1 \%$ ) cilvēki (4. tab.). Luize Neilande no Sīpeles pagasta par tēvatēvu Juri Būdu teica, ka viṇš miris 80 gadu vecumā, Lĩvbērzes pagasta iedzīvotāja Līna Freimentāls par vectēvu Kristapu Zommeru stāstịja, ka viṇš miris 90 gadu vecumā, bet Kristaps Brūms no Bērzmuižas pagasta atcerējās, ka viṇa tēvatēvs Krišs Brūms nodzīvojis 80 gadu. Pēc soo trīs cilvēku sacîtā, kuriem pašiem 1939.gadā bija 84-97 gadi, vinuu vectēvu mūža vidējais ilgums bijis 83,3 gadi.

Ziṇas par mātestēvu šajā vecuma grupā sniedza tikai 3 cilvēki $(11,1 \%)$, apliecinot, ka vinu vectēvi mātes līnijā dzīvojuši no 80 līdz 90 gadiem (vidēji 83,3 gadus).

Tã kã ziṇas par tēvatēva un mātestēva miršanas vecumu ir visai līdzīgas (5. tab.) un neuzrāda lielas atš̌kirīības arī pēc vecuma grupām, tās aplūkotas kopumā. No aptaujātajiem (60-90 gadu veciem sirmgalvjiem) ziṇas par vectēvu mūža ilgumu sniedza $29-49 \%$. Iznēēmums bija visvecākie, no kuriem tikai $22 \%$ atcerējās savus pirms 19. gs. dzimušos vectēvus. Tomêr vinuu sniegtās liecības nebija pretrunīgas, tās labi iek|āvās jaunāku gadu gājuma cilvēku sniegtajās ziṇās, apliecinot, ka vectêvu mūža ilgums svārstîjies no 70 līdz 90 gadiem, dažiem pat līdz 115 gadiem. Tãdus datus par sava tēvatēva Kārla Šturma 115 gadus ilgo mūžu sniedza 80 gadu vecā Anete Ulmanis, dzimusi Šturma, no Bērzmuižas pagasta. Lìze Lasmanis no Vilces atcerējās, ka vinas tēvatēvs Krišjānis Linbergs no Kalnamuižas nodzīvojis 110 gadu. Krišjānis Lešinskis no Bukaišiem stāstīja ka, ilgdzīvotības rekordu, nodzīvodams līdz 124 gadiem, uzstādījis viṇa têvatêvs (kam viṇš gan bija aizmirsis vārdu). Iespējams, ka šie dati varētu atbilst patiesībai, ja ṇemam vērā, ka aptau- 
jātajiem, kā jau minējām, bija dzīvi tēvi, kas bija 97-100 gadu veci. Cilvēki, sākot no 74 gadu vecuma, un paaudze kopumã, atceras, ka dala vecotēvu miruši spēka gados un mūža pilnbriedā (40-45 gadu vecumā). Ticams ir arī vecotêvu vidējais mūža ilgums 72-77 gadi (bez bērnu mirstỉbas rādītājiem), kādu sniedza vecākās grupas aptaujātie. Atcerēsimies, ka ziṇas sniedza cilvēki, kas paši 1939. gadā bija vecāki par 64 gadiem.

Atmiṇas par vecāmmātềm (gan tēva, gan mātes līnijā) 1939: gadā sniedza 15-41\% cilvēku, kas dzimuši 1842.-1880. gadā (6. tab.). Vissliktāk tās atcerêjās visvecākā iedzīvotāju grupa (1842.-1855.g. dzimušie), labāk - 26\% gadījumu - 1856.-1860.g. dzimušie aptaujātie. Sākot ar 74 gadu vecumu, visu pārējo vecuma grupu aptaujātie savas vecāsmātes atcerējās $38-45 \%$ gadījumu, daži zināja arī viṇu mūža ilgumu un nāves cēloni. Kopumã atmiṇas par mātesmāti tikai dažos procentos gadījumu bija sliktākas nekā par tēvamāti. Atsevišķos gadījumos, īpaši jaunākajā vecuma grupā (1876.-1880.g. dzimušiem), tâs bija pat labākas. Mătesmātes mūža ilgumu zināja ceturtā da|a aptaujāto.

Jāatzīmē, ka līdzīgi kā vectēvu gadījumā, arī izvêrtējot mūža ilgumu mātesmātēm, parādās divas tendences. Pirmã liecina par visai ilgu mūžu, reizâm pat ar mītisku nokrāsu. Tā, Paulīne Velve, dzimusi Ķīverts, no Bērzmuižas atcerējās, ka viñas mātesmāte Marija (uzvārdu neatcerējās) nodzīvojusi līdz 115 gadiem. Interesanti atzīmēt, ka viñas māsa Marija Kviesis, dzimusi K̦īverts, to bija aizmirsusi, tāpat viṇa neatcerējās tēvamātes mūža ilgumu, ko Paulīne atcerējās kā 60 gadu ilgu. Arī mātes mūža ilgumu māsas atcerējās dažādi - Paulīne minēja to kā 90 gadu ilgu, bet Marija - 100 gadu ilgu.

Pēc 94 gadu vecās Līnes Freimentāles, dzimušas Zommeres, atmiṇām, 110 gadu nodzīvojusi arī viṇas têvamāte Grieta (uzvārdu neatcerējās), kas, spriežot pēc paŠas aptaujātās gadiem, izklausās visai ticami. Arī Sīpeles pagasta iedzīvotājs Kristaps Vidiṇ̂̌ zināja stāstît, ka viṇa tēvamāte, kurai viṇš bija aizmirsis gan vārdu, gan uzvărdu, nodzīvojusi 100 gadu.

Otra tendence, kas parādās cilvēku atmiṇās, stāstot par savām vecāmmātēm, ir šăda - cilvēki reāli atceras arī vecâsmātes agro nāvi un tās cēloṇus. Da|a no vinăm mira jaunas $-27,35$, vai 40 gadu vecumā. Tomēr vidējais mūža ilgums (neietverot tajā bērnu mirstības rādītājus) bijis aptuveni 75,7 gadi. Spriežot pēc cilvēku atmiñăm, tas pārsniedza mātes mūža ilgumu. Vai tas atsedz reălo ainu, tas gan vēl jāpārbauda. 
1. tabula. Zemgales novada I paaudzes vecuma struktūra (pa pagastiem) pēc 1939. g. antropologisko ekspedīciju materiāliem

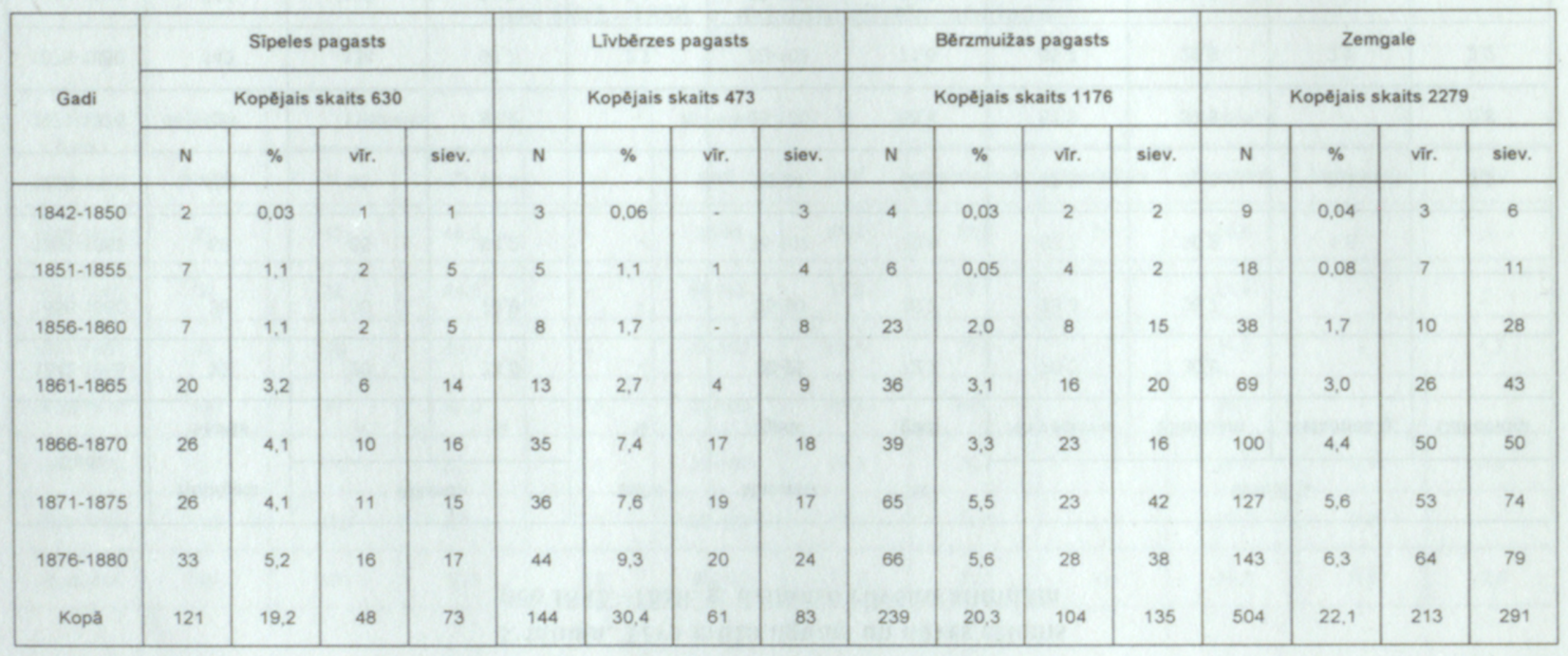


2. tabula. Tẽva mũža ilgums un nāves cēlonis pēc 1842.-1880. g. dzimušo cilvēku atminăm

\begin{tabular}{|c|c|c|c|c|c|c|c|c|c|c|}
\hline \multirow{2}{*}{ Gadi } & \multirow{2}{*}{$\begin{array}{c}\text { Kopêjais } \\
\text { skaits }\end{array}$} & \multicolumn{2}{|c|}{ Atceras } & \multirow{2}{*}{$\begin{array}{l}\text { Dzivi } \\
\%\end{array}$} & \multirow{2}{*}{$\begin{array}{l}\text { Min-max } \\
\text { gadi }\end{array}$} & \multirow{2}{*}{ M } & \multicolumn{4}{|c|}{ Miruši \% } \\
\hline & & n & $\%$ & & & & No vecuma & Slimibăm & Nelaimes g. & Citi cêloni \\
\hline $1842-1855$ & 27 & 20 & 74,0 & - & $30-95$ & 72,2 & 70,0 & 30,0 & - & - \\
\hline $1856-1860$ & 38 & 30 & 78,9 & - & $35-90$ & 76,7 & 73,3 & 26,7 & - & - \\
\hline $1861-1865$ & 69 & 65 & 94,2 & - & $35-107$ & 70,8 & 67,7 & 30,8 & 1,5 & - \\
\hline $1866-1870$ & 100 & 93 & 93,0 & . & $30-94$ & 68,2 & 62,5 & 33,3 & 5,4 & 2,2 \\
\hline $1971-1875$ & 127 & 119 & 92,9 & - & $25-100$ & 68,4 & 61,3 & 37,8 & . & 0,8 \\
\hline $1876-1880$ & 143 & 134 & 93,7 & 2,2 & $30-102$ & 71,6 & 65,7 & 29,9 & 2,2 & 2,2 \\
\hline I paaudze & 504 & 460 & 91,3 & 1,1 & $25-107$ & 69,2 & 67,8 & 31,0 & 1,5 & 0,7 \\
\hline
\end{tabular}


3. tabula. Mātes mũža ilgums un nãves cēlonis pēc 1842.-1880. g. dzimušo cilvēku atmiṇām

\begin{tabular}{|c|c|c|c|c|c|c|c|c|c|c|c|}
\hline \multirow{2}{*}{ Gadi } & \multirow{2}{*}{$\begin{array}{l}\text { Kopêjais } \\
\text { skaits }\end{array}$} & \multicolumn{2}{|c|}{ Atceras } & \multirow{2}{*}{ Dzivas } & \multirow{2}{*}{$\begin{array}{l}\text { Min-max } \\
\text { gadi }\end{array}$} & \multirow{2}{*}{ Madi } & \multicolumn{5}{|c|}{ Mirušas \% } \\
\hline & & $n$ & $\%$ & & & & No vecuma & Dzemdibâs & Slimibâm & Nelaimes g. & Citi c. \\
\hline $1842-1855$ & 27 & 13 & 48,2 & - & $26-98$ & 68,6 & 76,9 & 7.7 & 10,5 & - & - \\
\hline $1856-1860$ & 38 & 32 & 84,2 & - & $56-102$ & 73,2 & 78,1 & - & 21,9 & - & - \\
\hline $1861-1865$ & 69 & 58 & 84,1 & - & $33-102$ & 65,6 & 72,4 & 1,7 & 24,1 & - & 1,7 \\
\hline $1866-1870$ & 100 & 87 & 87,0 & 2,0 & $37-100$ & 69,6 & 69,0 & 2,3 & 28,7 & . & - \\
\hline $1871-1875$ & 127 & 117 & 92.1 & 3.1 & $28-100$ & 70,4 & 76,1 & 1,7 & 20,5 & 0,9 & 0,9 \\
\hline $1876-1880$ & 143 & 125 & 87.4 & 7.0 & $26-102$ & 70,4 & 72,0 & - & 27,2 & 0.8 & - \\
\hline I paaudze & 504 & 432 & 85,7 & 3.2 & $26-102$ & 71,2 & 73,1 & 1,4 & 24,5 & 0,5 & 0,5 \\
\hline
\end{tabular}


4. tabula. Têvatễva mužza ilgums un nāves cêlonis

\begin{tabular}{|c|c|c|c|c|c|c|c|c|c|c|}
\hline \multirow{2}{*}{ Gadi } & \multirow{2}{*}{$\begin{array}{l}\text { Kopejais } \\
\text { skaits }\end{array}$} & \multicolumn{2}{|c|}{ Atceras } & \multirow{2}{*}{$\begin{array}{l}\text { Dzivi } \\
\%\end{array}$} & \multirow{2}{*}{$\begin{array}{l}\text { Min-max } \\
\text { gadi }\end{array}$} & \multirow{2}{*}{ M } & \multicolumn{4}{|c|}{ Mirusi \% } \\
\hline & & $n$ & $\%$ & & & & No vecuma & Slimibăm & Nelaimes $\mathbf{g}$. & Citi cêloni \\
\hline $1842-1855$ & 27 & 3 & 11,1 & - & $80-90$ & 83,3 & 100 & - & - & - \\
\hline $1856-1860$ & 38 & 5 & 13,2 & . & $70-115$ & 86 & 100 & - & - & - \\
\hline $1861-1865$ & 69 & 19 & 27,5 & - & $60-124$ & 77,9 & 100 & - & - & - \\
\hline $1866-1870$ & 100 & 26 & 26,0 & . & $45-103$ & 74,3 & 80,9 & 11,5 & 7,7 & - \\
\hline $1971-1875$ & 127 & 23 & 18,1 & 0,8 & $45-100$ & 74.2 & 87.0 & 8,3 & 8.3 & - \\
\hline $1876-1880$ & 143 & 34 & 23,8 & 1,4 & $45-100$ & 76,0 & 76,5 & 15,6 & 2.9 & 5.9 \\
\hline I paaudze & 504 & 110 & 21,8 & 0,6 & $45-124$ & 74,8 & 84,5 & 9,1 & 4,5 & 1,8 \\
\hline
\end{tabular}




\section{5. tabula. Mātestēva mũža ilgums un nāves cêlonis}

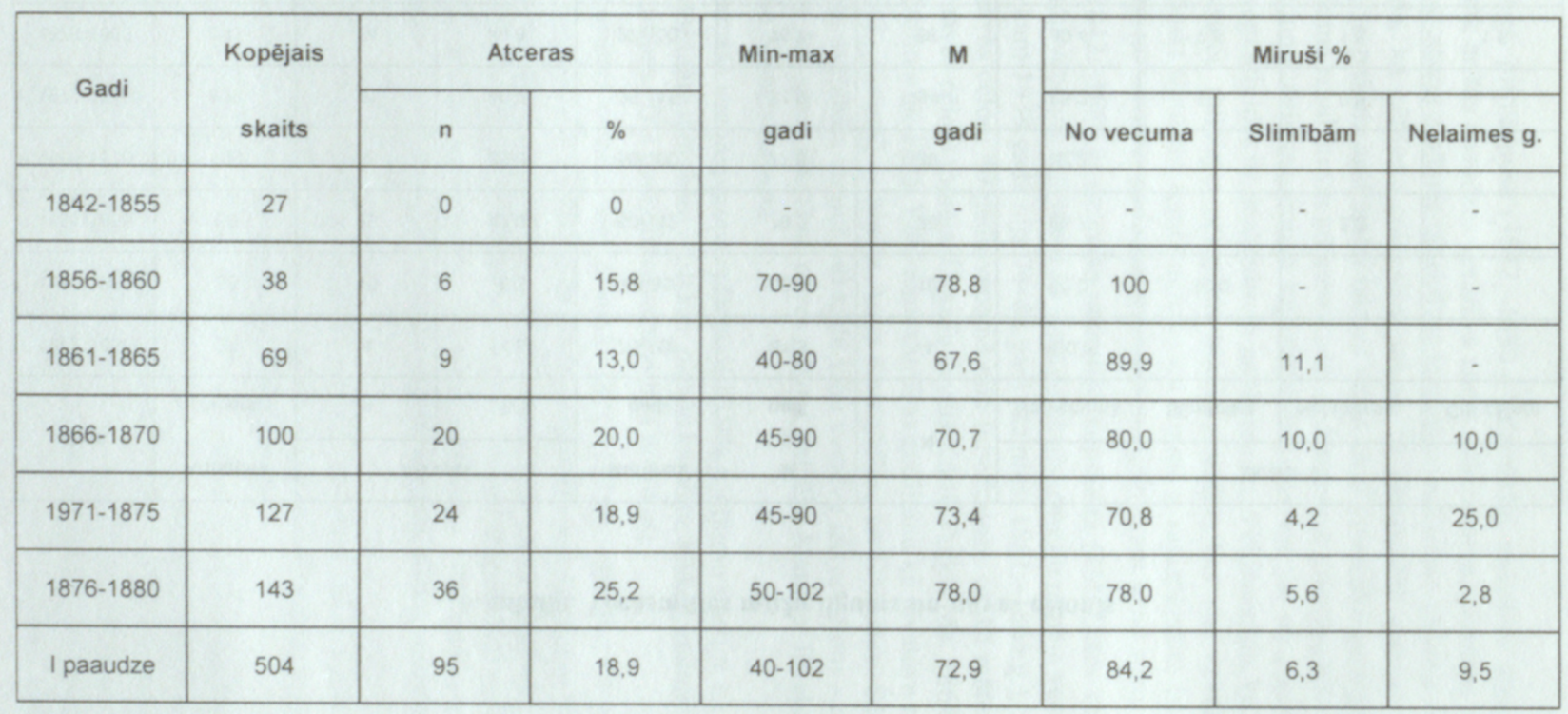




\section{6. tabula. Vecāsmātes mũža ilgums un nãves cēlonis}

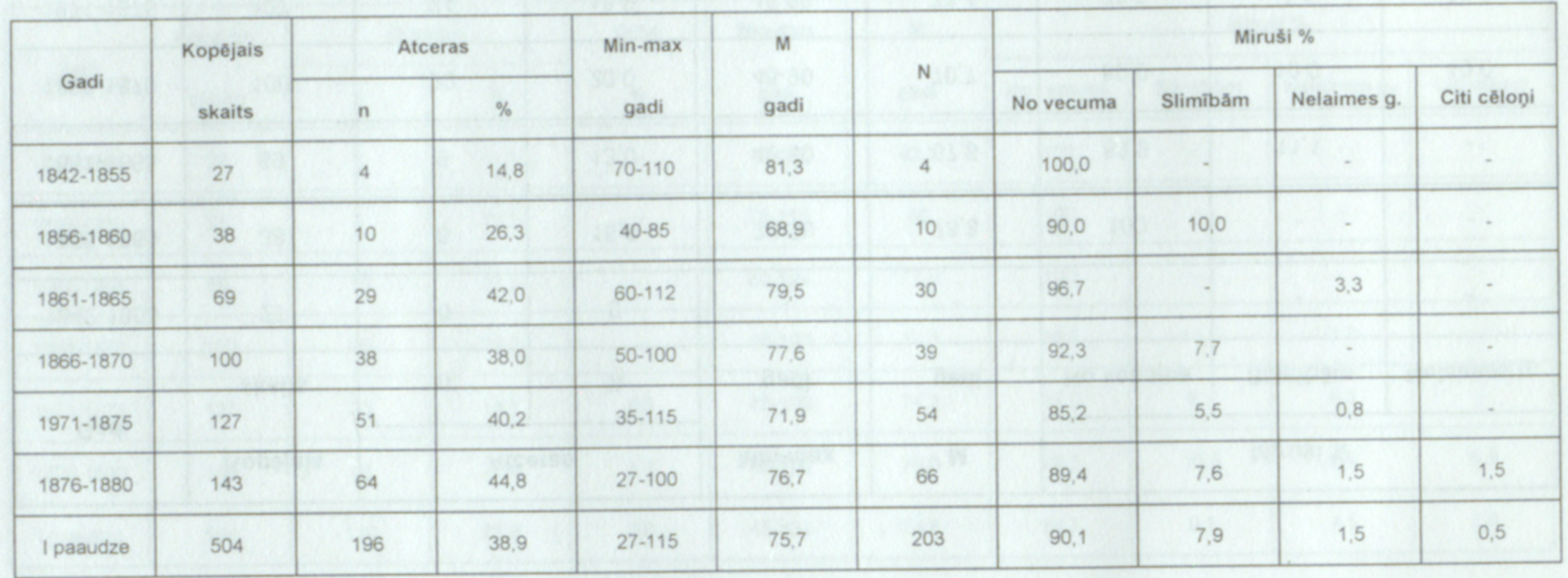




\section{Nãves cēloni}

Lai raksturotu 19.gs. pirmā pusē (1842.-1880.g.) dzimušãs paaudzes têvu mirŠanas cēloṇus, jāsāk ar šâs paaudzes vecātềva nāves cēloṇu noskaidrošanu (4. un 5. tab.). Tieši tã var atsegt zināmas objektīvas tendences mirstības cēloṇos. Pirms to darām, jānorāda, ka pētnieka priekšã ir izlase. Šĩ iedzīvotāju aptauja neatspogu|̣ laikmetu, jo pašreiz apskatāmi izlases veidā tikai visvecākā gadagājuma cilvēki, tāpēc pētîjuma rezultāti var arī nesaskanēt ar datiem par mirstību literatūrā. Taču arī šajā gadījumā dzimtas atmiṇā saglabājušãs ziṇas var vai nu papildināt zināmo, vai arī sniegt atbildes uz neskaidriem jautājumiem. Vēl jānorāda, ka ziṇas par dzimtas priekšteču miršanas cēloṇiem sniedz paaudze, kas var vairāk vai mazāk precīzi nosaukt slimības, tomēr nereti vinu atmiṇā ir saglabājušies t.s. tautas nosaukumi, kuri ne vienmēr padodas precīzam medicīniskam aprakstam.

No visai nelielā 1842.-1860.g. dzimušo aptaujāto kopskaita (26\%),kam vectēvi nomira 70-115 gadu vecumā, mazbērni kā vienīgo nāves iemeslu minēja vecumu. No aptaujātajiem, kam 1939.gadā bija 74-82 gadi (dzimuši 1861.-1865.g.), viens cilvēks kā agras nāves cēloni 40 gadu vecumā min tuberkulozi: to, kā mātestēva Jâna Nettenberga nāves cēloni minēja 75 gadu vecais Kārlis Pulkis (dz. 1864.) no Sīpeles pagasta (dzimtas nr. 129). Vēl vienu slimības gadījumu kā tēvatēva nāves cēloni - gan 70 gadu vecumā - minēja Anna Komandiers no Džūkstes. Šãs vecuma grupas cilvēki saglabāja atmiṇā vēl kādu vinu vectêvu nāves cēloni - nelaimes gadījumu. To kā sava têvatêva nāves cēloni minēja Matilde Jēkabsone, dzimusi Sniķere, no Sīpeles pagasta.

1866. -1870.g. dzimušãs vecuma grupas pārstāvji 10,9\% gadījumu stāstīja, ka viṇu vectēvi miruši no dažādām slimībām - triekas, plaušu karsoṇa, tūskas, reimatisma, kẩas iekšḳīgas slimības. Trīs gadījumos vectēvi bija noslīkuši.

Jaunākas vecuma grupas cilvēki, kas dzimuši 1871.-1875.g., slimību kā nāves iemeslu minēja $17 \%$ gadịjumā. Lielākā da|a (četri gadījumi) vectēvu mira ar trieku, vienã gadījumā nāves cēlonis bija tūska, citi mira ar tîfu un nieru slimībām. Trīs cilvēki kā nãves iemeslu minēja nelaimes gadījumus. Visjaunākie no Zemgalē aptaujātajiem vecākās paaudzes cilvēkiem (dz. 1875.-1880.g.) 10\% gadījumu kā vecātēva nāves cēloni minēja slimību - trieku, plaušu karsoni, tūsku, sirdstrieku, vienā gadījumā holeru un audzēju.

Kopumā, spriežot pēc 1842.-1880.g. dzimušo cilvēku atmiṇām, tikai katrā desmitā gadījumā nāves cêlonis bija slimības, mazliet vairāk cilvēku gāja bojā nelaimes gadījumos, bet vairākums mira vecuma nespēka dē].

Analizējot šâs paaudzes atmiñas par vecāsmātes nāves cēloni, vispirms jāatzīmē, ka tẩs visãs vecuma grupās ir vājākas nekā atminas par tềvu (6. tab.). Atmiṇas par mātesmāti ir nedaudz labākas nekā par tēva māti. Kopumā, pēc mazbērnu atmiṇām, $90 \%$ vecomāšu mira no vecuma. Tiesa gan, aplūkojot šo rādītāju atsevišķās vecuma grupās, var konstatêt, ka cilvēku skaits, kas mirst no slimībām, pieaug no aptaujāto vecākâs grupas uz jaunāko; visai iespējams, ka tam ir arī objektīvs cēlonis. 
Salīdzinot ar līdzīgu rādītāju vīriešu grupā, tēvu identitāti atceras vairāk aptaujāto, bet pēc saslimstības rādĩtāji ir gandrīz vienādi (10 un $8 \%$ ); vĩriešiem lielāku procentu veido nelaimes gadījumos bojā gājušie, sievietêm tas ir neliels $(1,5 \%)$.

Pēc slimỉbu analīzes redzam, ka ir atsevišķi gripas, holeras, tuberkulozes, plaušu karsoṇa, asinssērgas gadījumi, kas, iespējams, ir epidēmijas sekas. Jānem vērā, ka izpētes grupu faktiski pầrstāv izlase. Faktu par epidēmijām balsta atmiṇas: Jānis Neilands (dz. 1875.g.) atcerējās, ka tēvamâte mirusi 50 gadu vecumā ar tīfu vienlaikus ar mātestēvu, kas arī bijis tīfa upuris.

Kā izplatītākais šăs paaudzes vĩriešu miršanas cēlonis anketās tiek norādīts vecums. No vecuma nespēka miruši ap $70 \%$ iepriekšêjās paaudzes vīriešu. Pārējie $30 \%$ miruši slimību dẹ]. Jau šajā vecuma grupā iezīmējas tendence, kas rāda, ka arī 19.gs. apmēram trešdala cilvēku mirusi slimību dē|. Kã nāves cēloṇi minētas tuberkuloze, plaušu karsonis (5\%), holera (vienā gadījumā), izsitumu tĩfs (vienā gadījumā). Kopumā no slimībām miruši aptuveni $30 \%$ cilvēku dažādā vecumā, gan spēka gados, gan vecumā; vienā gadījumã tềvs miris 66 gadu vecumā no sirds slimības. 81 gadu vecais saimnieks Jānis Knochs no Bērzmuižas pagasta, stāstīdams par savu tēvu, kas miris 72 gadu vecumā, par viṇa nāves iemeslu minēja kuṇga vēzi. Ja minētã diagnoze ir pareiza, tad, iespējams, tas ir Latvijā vecākais saslimšanas gadījums ar vẽzi.

Jāatzīmē, ka nāves cēloṇu vidū tautas valodā tiek nosaukti "neatpūta" ( 55 gadu vecumā), "galvas krampji" (40 gadu vecumā); minēts arī viens alkoholisma gadijjums (45 gadu vecumā), ko par têva nāves cēloni minējis Andrejs Neimanis no Kalnciema pagasta. Kã nāves cēlonis minēts, piemēram, ievainojums turku karā, kura dē| cilvēks miris 50 gadu vecumā. Kâdā veidlapā par nāves cêloni minētas bailes, citãs minēti nelaimes gadījumi $(1,5 \%)$.

Kādas bija izplatītākās slimības, kas varēja būt par nāves cēloni?

Pirmajā vietā minēta trieka $(3,7 \%)$, bet otrajā vietā - tuberkuloze $(3,1 \%)$, no kuras mira gan jaunībā (25-30 gadu vecumā), gan vecumā; no šîs slimības mirušo cilvēku vidējais vecums bija 46,8 gadi (tūlît pēc bakâm, no kurâm mira 30-45 gadu vecumā). Trešajā vietā kā nāves cēlonis minēta tūska $(2 \%)$. No krūšu slimību izraisītiem sarežg̀ijumiem miruši 1,7\% tēvu, no plaušu karsoṇa - 1,3\% iepriekšejjās paaudzes vīriešu.

Mātes nāves visizplatîtākais cēlonis bija vecuma nespēks. Minētas arī vairākas slimības, kas bijušas par nāves cēloni gandrīz $30 \%$ sieviešu. Saskaņā ar bērnu atminâam, agra nāve (26 gadu vecumā) bijusi saistîta ar dzemdībām. Minēti gadījumi, kad nāvi izraisījusi pneimonija. Līvbērzietis Ansis Vịksna, stāstot par mātes Katrīnas, dzimušas Brancis, nāves cēloni minējis rozi.

Kopumā, kã tas atspogu|jojas cilvēku atmiṇā, 19.gs. sākumã gandrīz 70\% cilvēku mira aiz vecuma, apmēram trešda|ja no slimībām; retāk nāves cēlonis bija nelaimes gadījums. Šie fakti ir pãrliecinoši, jo par tiem runā visu vecuma grupu cilvēki. Spriežot pēc atmiṇām, no slimībām, kas, izraisīja nāvi, pirmajā vietã minēta trieka 
(izraisīja nāvi $5 \%$ vīriešu un 3\% sieviešu). Otrajā vietā pēc saslimstības biežuma bija tuberkuloze - nāves cēlonis $3,4 \%$ vīriešu un $2,8 \%$ sieviešu. Seko tūska, kas izraisīja nāvi $2 \%$ vĩriešu un $1 \%$ sieviešu, tad krūšu slimības, no kurām mira $1,7 \%$ vīriešu un $0,2 \%$ sieviešu, un plaušu karsonis - nāves cēlonis $1,3 \%$ vīriešu un $2,3 \%$ sieviešu. Kā liecina cilvēku atmiņas, no plaušu karsoṇa vairāk mira sievietes. Kā atsevišksas slimības, kas izraisījušas nāvi, minētas astma (1,3\% vĩriešu un 1,5\% sieviešu), izsitumu tīfs ( $1,1 \%$ vīriešu un $0,5 \%$ sieviešu) un bakas. Ipaši jāizce| kungga vēzis, ar kuru mira 1,5\% vīriešu. Cilvēku atmiñas liecina, ka jau tolaik sievietes slimojušas ar krūts vēzi.

Lai objektīvāk spriestu par slimībām, kas piemeklēja 19.gs. sākumā Zemgales novadā dzimušos, jāpievēršas datiem, kas atrodami medicīnas vēstures literatūrā. To gan nav daudz un, iespējams, ka literatūra sniedz visai vienpusīgu ieskatu. Vairākums pētnieku, kas rakstījuši par slimībām, kādas bija izplatītas Baltijas gubernās 19.gs. sākumā, norāda uz infekcijas slimībām, pēc kurām Krievija ieṇēma vienu no pirmajām vietām pasaulē. Katru gadu Krievijas Eiropas da|ā kopējā mirstība bija 31,2-40,5 cilvēku uz 1000 iedzīvotājiem. No izplatītākajām infekcijas slimībām pētnieki min holeru, mēri, malārịju, gripu, tīfa parazìtiskās formas, zarnu slimības un bẽrnu infekcijas slimības. ${ }^{8}$

Viena no visbiežāk sastopamām slimībām, turklāt ar epidēmisku un pat panepidēmisku raksturu, bija holera, kas bija izplatīta arī 19.gs. un pat 20.gs. sākumā. Pētāmo paaudzi varēja skart 1818.-1823. gada holeras epidēmija, vai arī nākamā, kas plosijāas Latvijā 1826.-1837. gadā. Taču Zemgales novada vecākās grupas iedzìvotāji (dzimuši no 1842. līdz 1855.g.) savās atminas par vecākiem neapstiprina pieñēmumu, ka iepriekšejāa paaudzē daudz cilvēku būtu miruši tieši holeras dē]. Vilis Derums, kas, škiet visvairāk pētījis seno latviešu slimības, visai plašă rakstā norāda, ka jaunākais holeras uzliesmojums, par ko rakstīja arī Latviešu Avizzes, bijis 1831. gadā Vidzemẽ un Kurzemē un ar pārtraukumiem ildzis līdz pat 1892. gadam. 1830. gadā Latviešu Avīzes raksta par holeras epidēmiju: Jelgavas aprinḳī no 4. jūlija līdz 28. septembrim saslima 1912 cilvēki, bet nomira - 968 . 1849. gadā Kurzemē pēc 7. septembra saslima 102 cilvēki, bet nomira 63, bet Vidzemēe epidēmijā, kas sākās 6.jūlijā, saslima 153 cilvēki, no kuriem nomira 100. Līdzīgi saslimšanas un mirstības rādītāji minēti 1852.- 1853.g. epidēmijā, kā arī 1855. gada epidēmijā, kas plosījās Kurzemē no 8. aprīla līdz 22. novembrim, kad saslima 453, bet nomira 210 cilvēku.

Kā jau minējām, šie dati nesaskan ar vecākās paaudzes cilvēku atmiṇām, taču parādās vidējās paaudzes atmiṇās par vecākiem un vecvecākiem. Citu slimību vidū, kuras bija sastopamas 19.gs. sākumā, V. Derums, kā arī citi autori, min asinssērgu (acīmredzot dizentēriju), kas epidēmijas veidā 1850. gadā plosỉjās Liepājas apkārtnē. Turklāt tā bijusi sastopama tik bieži, ka "nebijis nevienas mājas, kur nebūtu slimojis vismaz viens cilvēks". Miruši galvenokārt bērni un veci cilvēki. Dažu pētnieku, arī V. Deruma ${ }^{10}$, pieminētās slimības, piemēram, skorbutu un kaški, neatzīmē neviens no aptaujātajiem. 
Rezumẹjot, jāsaka, ka atmiņas ir visai interesants vēsturiskus datus papildinošs materiāls - medicīnas vēsturnieki biežāk fiksē un sniedz bojāgājušo cilvēku skaitu, bet dzimtas atmiṇas norāda arī uz slimību pârdzīvojušiem cilvēkiem. Katrā ziṇā šis materiāls vēl gaida apkopojumu. Pārskats par 1842.-1880.g. dzimušo zemgaliešu atmiṇām par viṇu vecākiem un vecvecākiem, to mūža garumu un nãves cēloni, ir pirmais mēginājums atklāt svarīgus un nozīmīgus vēstures aspektus caur cilvēku atmiṇu prizmu. Vai šie materiāli k|ūs par populāru vēstures avotu, tas jānoskaidro turpmākos pētijumos.

\section{Atsauces un skaidrojumi}

1 Jēkaba Prīmaṇa Anatomijas muzeja 7. fonds, kārtas Nr. 11590-12220, 2 ank.971 Ank. Ekspedīcijas sastāvā Dr. K. Arājs, Dr. N. Lūkina, laborante Tãlberga.

2 Turpat. 8, fonds, kārtas Nr. 12228-12700, ank. Nr. 982-1761.

3 Turpat. 9./10. fonds, kārtas Nr. 12701-13876; Ank. Nr. 12701-17700.

4 Straubergs J. Sīpeles pagasts senās dienās: Sīpeles pagasta pašvaldība. - 1936. - 23. lpp.

5 Turpat. 18. Ipp.

6 LVVA, 630. fonds, 1. apr., 407 lieta.

7 Turpat.

8 Дерумс В. Я. О естественном движении населения Латвии в XIX веке// Из истории медицины. - Рига: Звайгзне, 1962. - Т. IV. - С. 45-57.; Дерумс В. Я. О диагностике некоторых болезней в Прибалтике в конце XVIII и начале XIX века// Из истории медицины. - Рига: Авотс, 1980. - Т. XII. - С. 59-64.; Васильев K. Г. Развитие отечечественной эпидемиологии в XIX веке// Из истории медицины. - Рига: Звайгзне, 1959. - Т.2. - С. 101-114.; Его же. Из истории борьбы с эпидемиями сыпного тифа в Прибалтике // Turpat. - C.161-163.

9 Derums V. Dažas seno latviešu slimības// Padomju Latvijas Ärsts. - 1940, - Nr.2. Derums V. Par asinsnolaišanu seno latviešu dziedniecībā// Ārsts. - 1940. - Nr.8. [Atsevišks novilkums.]

10 Derums V. Ārstnieciskā palīdzība latviešiem 18.gs.beigās un 19.gs. sākumā/l Padomju Latvijas Ārsts. - 1941. - Nr.1. - 69.-77. Ipp; Васильев К. Г., Богачева Р. П., Вайдерс Л. Л. К истории холерных эпидемий в Латвии в XIX-XX столетиях// Из истории медицины. - Рига: Звайгзне, 1962. - Т. IV. - С.65-77.

\section{Some Causes of Death and Reasons of Life Span of the $19^{\text {th }}$ Century Inhabitants of Zemgale According to Anthropology Expedition Data (Summary)}

By Rita Grāvere

In 1939 the Anatomical institute of the Latvian University together with the Institute of Nations Life Power has put into practice the programme of anthropological investigations during June and the end of summer in three parishes (Sīpele, 
Līvberze, Bērzmuiža) - 1176 persons have been investigated; an important place was devoted to social anthropology questions. In this questionnaire, which was formed by J. Primanis Anatomy institute collaborators together with those of the Institute of Nations Life Power, were included a series of demographic, genealogical, medical and socially motivated questions. From all these social anthropology questions in 1939 the investigation -included memories of the older generation questioned (born 1842-1880) about the life span of their parents and grandparents (the lines of father and mother) and the causes of their death.

About $91.3 \%$ of the questioned could name the causes of the life span of their fathers. $93-94 \%$ of the older generation (aged 59-74) have kept memories about the life span of their fathers. Elderly people, after 83 had weaker memories. The oldest generation of Zemgale estimated the life span of their fathers as being from the age of 25 up to 107 (the average being 69.2 years). The majority of the previous generation died of old age (almost $75 \%$ ), $31 \%$ died of diseases, $1.5 \%$ of cases suffered lethal accidents.

$87-92 \%$ of the questioned gave information concerning their mothers' life span. However, from the oldest people (born from 1842 to 1855 ) only $48.2 \%$ remembered the life span of their mothers. The life span of women of the previous generation alternated from 26 to 102 years (the average being 71.2 years). In most cases was the cause of death mentioned was during labour and delivery $(19 \%)$. However, $73.1 \%$ of mothers had died from old age, white $24.5 \%$ from various diseases.

Only $21.8 \%$ of those questioned could give information about their father's father, while still fewer ones about their mother's father $(18.9 \%)$. Their grandfathers' ages were from 40 up to 124 years. Men of this generation died mostly of old age; only $6-9 \%$ died of diseases.

The older generation of Zemgale could give information about their grandmothers only in $38.9 \%$ of cases. Those who were questioned evaluated their age from 27 up to 115 years. The cause of early death in these cases was also death during child - birth.

On the whole according to people's memories, almost $70 \%$ of persons at the beginning of the $19^{\text {th }}$ century died because of old age one - third from diseases, and more seldom it was caused by accidents

Rita Grāvere, Dr. hist.

Jēkaba Prīmaña Anatomijas muzejs

Kronvalda bulv. 9.

Rīga, LV-1010

Latvija 
